\title{
Bioethica
}

Vol 1, No 2 (2015)

Bioethica

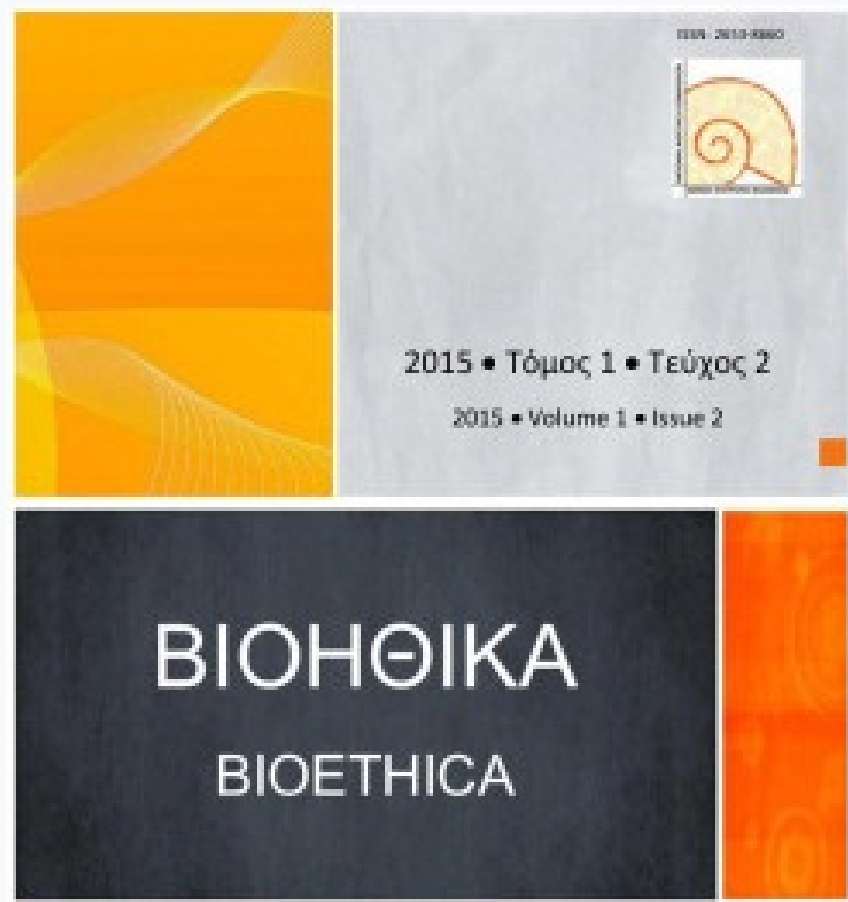

Does luck egalitarianism lose its appeal in the face of genetic engineering?

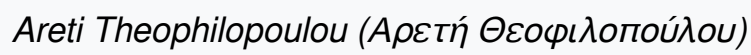

doi: $10.12681 /$ bioeth. 19648

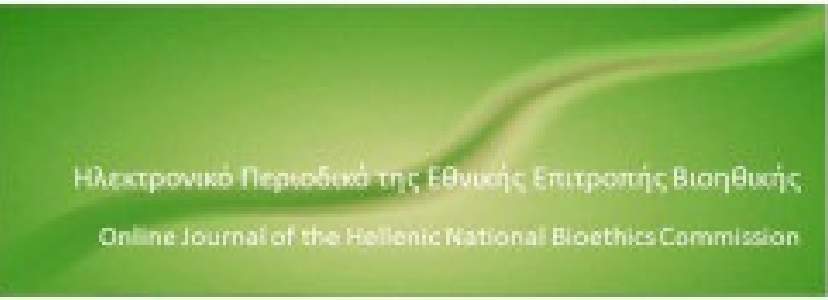

To cite this article:

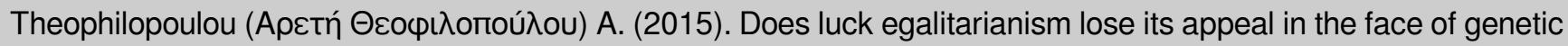
engineering?. Bioethica, 1(2), 11-24. https://doi.org/10.12681/bioeth.19648 


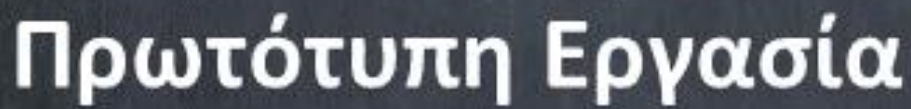

\section{Does luck egalitarianism lose its appeal in the face of genetic engineering?}

\section{Areti Theophilopoulou, MSc}

\begin{abstract}
It has been suggested that the era of genetic interventions will sound the death knell for luck egalitarianism, as it will blur the line between chance and choice, on which theories of distributive justice often rest. By examining the threats posed to these theories, a crucial assumption is exposed; it is assumed that a commitment to the neutralisation of the effects of luck implies the endorsement of even the most morally controversial enhancements. In antithesis, I argue that an attractive theory of luck egalitarianism, Dworkinian liberal equality, enables us to deduce plausible implications for genetic engineering. By focusing on the abstract moral commitments at the heart of Dworkin's theory, a twofold purpose is served. First, they reveal in what ways the criticisms misfire, thereby safeguarding luck egalitarianism. Second, Dworkinian luck egalitarianism is further strengthened, as it produces plausible guidelines for public policy on genetic engineering in liberal societies.
\end{abstract}

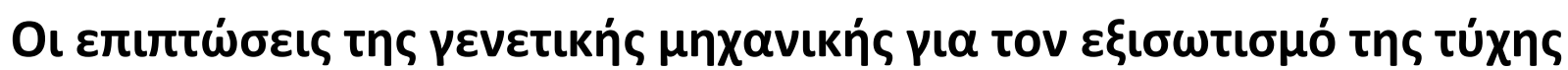

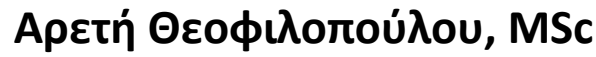

\section{Пєрí $\eta \psi \eta$}

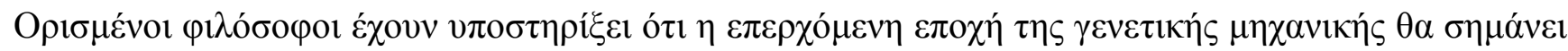

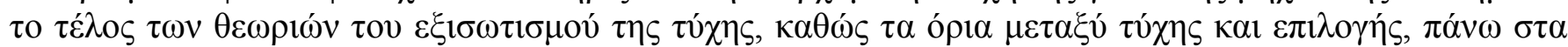

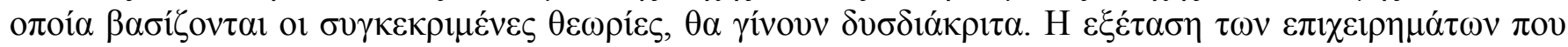

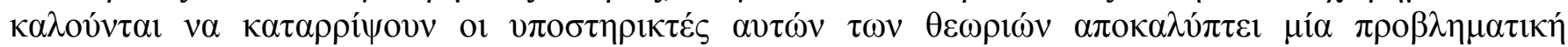

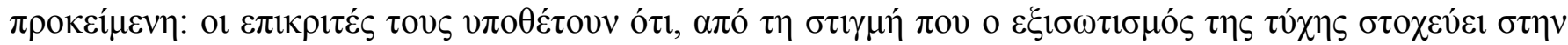

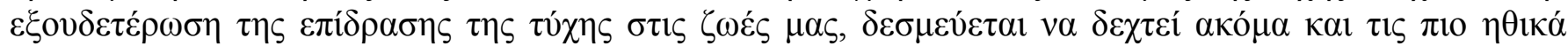

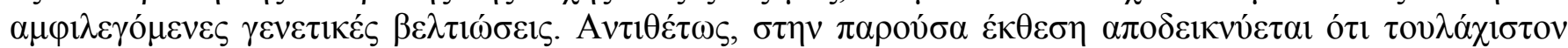

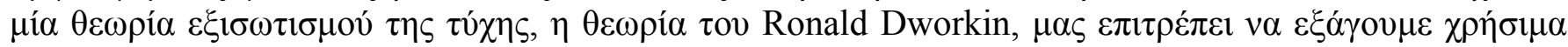

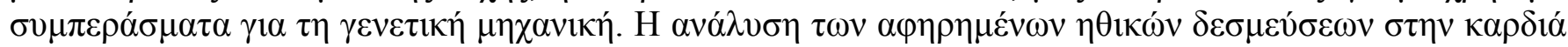

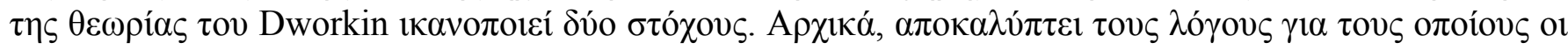

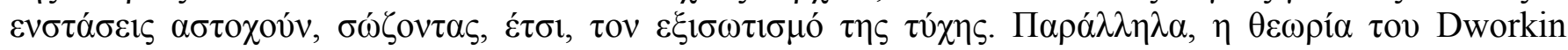

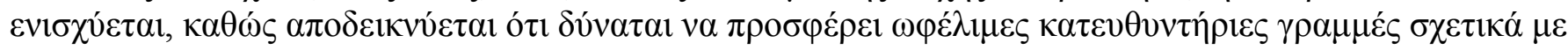

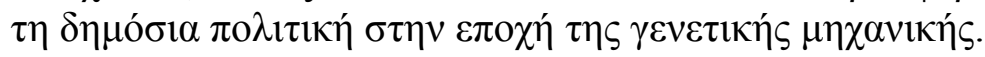




\section{Introduction}

As genetic engineering becomes a technologically feasible possibility, terrifying images from Aldous Huxley's Brave New World are born; images of a world of grave inequalities and robot-like people ${ }^{1}$. Yet upon reflection, one wonders whether this intuitive reaction is simply another manifestation of the fact that humans have always been biased in favour of the status quo and suspicious of radical change. The burden of argumentative clarity thus falls upon philosophers, who are expected to disentangle argument from bias, reasons for action from the fear of the unknown.

It is thought that the era of genetic engineering, namely of genetic therapy and enhancement, will uncover the shaky roots of some theories, by exposing their implications for genetic interventions; in antithesis, the plausibility of other theories will immediately be highlighted. In particular, responsibility-sensitive theories of justice are expected to face challenges, in virtue of their distinction between the moral significance of choice as opposed to chance. Indeed, numerous theorists have argued or implied that luck egalitarianism will fall into the first category of theories ${ }^{i}$. This is because, it is argued or assumed, the philosophical commitments of luck egalitarianism imply adherence to the concept of genetic equality, which seems morally reprehensible for a variety of reasons. An analysis of this argument is offered in the first part of this thesis. Subsequently, I examine the particular problems that the concept of genetic equality seems to pose to luck egalitarianism; assuming that the latter implies prescription of the former, I expose the internal fallacies of these claims, to prove that even if the basic argument were valid, it would not immediately sound the death knell for luck egalitarianism.

I contend, however, that luck egalitarianism need not imply that genetic equality is desirable. In order to prove why this is so, and more importantly, what luck egalitarianism does require in the face of genetic

\footnotetext{
${ }^{\mathrm{i}}$ Luck egalitarian theories of justice claim that inequalities resulting from brute, i.e. unchosen, luck, are unfair.
}

engineering, I rely on a particular conception of liberal equality, Dworkinian luck egalitarianism $^{\text {ii }}$. I thus deduce from the central commitments of this theory which interventions are required, which ones are simply permissible, and which ones are strictly impermissible $\mathrm{i}^{\mathrm{iii}}$.

It should be stressed that although I rely on Dworkin's ideas, my pursuit is not to interpret and spell out the exact implications of Dworkin's luck egalitarianism. Rather, I aspire to demonstrate how an attractive conception of luck egalitarianism, which is based on Dworkinian political morality, avoids certain criticisms, and gives rise to a compelling theory of justice in genetics. As long as there is commitment to antiperfectionist public policy, different luck egalitarian theories may also reach similar conclusions. The imminence of genetic interventions, however, does give us reason to reject theories, luck egalitarian or not, that cannot offer satisfying responses to the worries analysed in Part I.

A central assumption that underlies my pursuit should be clear: I generally assume an ideal level of risk, effectiveness, and availability to individuals from different social classes throughout the paper, in order to focus on the philosophical implications of luck egalitarianism for genetic engineering. It should be stressed that, although most of the techniques the article examines are not yet feasible, we ought to consider them for three reasons. First, if they discredit luck egalitarianism, one of the most prominent theories in contemporary political philosophy, they may present a reason to abandon the theory, even if we only reach a limited number of these technological advances. Second, there is a wide belief that at least some of these technologies will be available in the near future and if so, it will be useful to be prepared

\footnotetext{
ii In order to neutralise the effects of brute luck on the distribution of resources, Dworkin proposes a scheme that is sensitive to individuals' ambitions (via a hypothetical auction) and insensitive to their endowments (via a hypothetical insurance market). See Dworkin, R. Sovereign Virtue: The Theory and Practice of Equality. Harvard University Press, 2000.

iii These conceptual distinctions are especially serious for the case of subsequent generations; namely, what luck egalitarianism implies for interventions on persons that will come to existence.
} 
on how we will assess them both morally and legally $^{2}$. Lastly, a theoretical pursuit of this kind has value on its own, as it enables us to refine and clarify our moral convictions.

\section{Part I: Criticisms of Luck Egalitarianism in the Genetic Era}

\section{The Basic Argument}

The main argument against luck egalitarianism in the face of genetic engineering, which also forms the basis of further charges, views those theories of justice as requiring absolute genetic equality. The 'brute luck view of the level playing field conception of equality of opportunity', as Buchanan et al name it, has undesirable consequences for genetic engineering in virtue of its commitment to the equalisation of opportunities that spring from circumstances individuals cannot control ${ }^{3}$. To see how this may follow, let us examine the basic commitments of luck egalitarianism: the theory requires that the distribution of the benefits and burdens of social cooperation be sensitive to option luck and insensitive to brute luck. The latter requirement gives rise to a societal obligation to redress inequalities that arise due to brute luck. Thus, in order to see what a principle of redress requires, we ought to turn brute luck into option luck, as Dworkin's hypothetical insurance scheme does ${ }^{4}$.

The argument advanced by Buchanan et al may be reconstructed as follows. Genetic inequalities arise due to brute luck; genetic engineering turns brute luck in the natural lottery into option luck; therefore, luck egalitarianism requires endorsing all forms of genetic engineering, as they turn brute luck into option luck. Now this last claim may initially seem unproblematic, if not a point of strength for luck egalitarianism, which highlights the arbitrariness of natural inequalities. Yet, as the additional criticisms that will be examined shall reveal, the concept of genetic equality presents numerous problems.

Now, a further complication of this argument is that it identifies such genetic interventions as obligatory. To the extent that brute luck can literally be turned into option luck, as happens in a one-generation case, a caveat may be formulated in order to protect individuals' liberty; interventions should not be obligatory if individuals are in a position to choose their genetic makeup themselves. Yet in the case of subsequent generations, brute luck can be turned into option luck in a way that does render interventions obligatory by this line of argument. If the state imposes genetic equality, there will be no inequalities arising from natural endowments. Natural brute luck will then be eliminated, leaving the space it normally occupies to individuals' option luck. If this can actually be achieved with minimal risk, as has been stipulated, luck egalitarianism requires all interventions that will induce genetic equality.

Luck egalitarians' critics build on this basis to identify further reasons for which the conclusions reached by the basic argument are morally repugnant. Nevertheless, by developing a theory of just genetic interventions that follows from Dworkinian luck egalitarianism, it will become clear that the criticisms examined in Part I are based on a misunderstanding of the necessary central commitments of luck egalitarianism. Although certain formulations of the theory may be vulnerable to these objections, I will argue that deriving luck egalitarian commitments from Dworkin's ethical individualism is one plausible way of safeguarding luck egalitarianism.

\section{Luck Egalitarianism and Libertarianism}

On the assumption that luck egalitarianism requires genetic equality as expounded in the previous section, it has been argued that, due to its commitment to ambition-sensitivity, the theory collapses into libertarianism ${ }^{5}$. The claim is that since individuals ought to face the consequences of their option luck, and since genetic engineering turns brute luck into option luck, individuals ought to accept the inequalities that arise due to their natural endowments. Even if some refrain from using genetic technologies, their genetic inequalities will not have to be redressed, for they will reflect their unwillingness to change, that is, a choice they have responsibly made ${ }^{6}$. This conclusion will serve to strengthen desert-based theories, as it will dismantle the objection that arbitrary natural 
inequalities cannot establish desert in unequal advantages. If individuals' choices reflect their ambitions, others should not be required to compensate them for any consequences that follow from those choices. Thus, what this argument aims to discredit, is not luck egalitarians' conceptual commitments, but the conclusions they typically deduce from them. Equality of resources or equality of access to welfare or advantage cannot be legitimate requirements of justice if agents simply deserve the full consequences of their choices.

Nevertheless, this argument oversimplifies the implications of the distinction between brute luck and option luck. First, considering that many interventions would be performed on embryos, brute luck in genetics would not be eliminated. As Dworkin points out, 'the fact that someone's genes have been designed by others, rather than chance or nature, and are in that way 'social', does not convert his genetic structure into option luck for him, ${ }^{7}$. Second, one's endowments are not limited to one's genetic makeup, but further include the effects of brute luck in the social lottery. For example, Dworkin stresses that 'the low-wage insurance presupposes, among the causes of unemployment and low wages, a host of social factors ${ }^{8}$. Therefore, in an era of genetic equality luck egalitarians would still have reason to support a strong welfare state.

\section{A Homogeneous World}

A different criticism of luck egalitarianism, which further seems to underlie numerous worries about genetic engineering, takes the following form. Certain traits are valued more than others, giving rise to an unequal distribution of the benefits and burdens of social cooperation. Since luck egalitarianism requires the pursuit of genetic equality, it implicitly requires the elimination of some traits and talents that are valued less. Thus, it has been claimed that luck egalitarianism in the face of genetic engineering would be, at least on a philosophical level, committed to constructing a homogenised world of nearly identical people $\mathrm{iv}^{\mathrm{v}, 9}$.

\footnotetext{
iv Buchanan et al grant that luck egalitarianism would not in fact prescribe complete genetic equality, due to complications relating to social policy. Yet they believe
}

The worry is that 'engineering might be used to perpetuate the occurrence of now desired traits of height, intelligence, colour and personality', thereby 'robbing the world of the variety that seems essential to novelty, originality and fascination, ${ }^{10}$. Moreover, given that the value we attach to traits is socially constructed, Farrelly argues that the endorsement of genetic equality is especially problematic, for it implies the perpetuation of temporally constrained values. Luck egalitarian prescriptions will thus prove to be self-defeating, as the traits of genetically modified individuals may come to be valueless under different circumstances ${ }^{11}$. Indeed, individuals that currently thrive in Western, liberal societies would lack the traits and talents that would be necessary to live well in agrarian societies.

However, the homogeneity objection rests on the dubious scientific assumption that phenotypes, such as the manifestation of talent, are wholly traceable back to a specific genotype, ignoring once again the significance of the social lottery ${ }^{12}$. More importantly, this objection makes the unjustified and implausible assumption that luck egalitarians must simply accept the values that the majority attaches to certain traits and talents, just like it does with resources. Dworkin's theory asks people to make their choices regarding resources by keeping in mind the value that others attach to those resources. The worry that underlies the homogeneity argument may be, for example, that because people value and reward blondes by giving them access to advantages, luck egalitarianism requires that we all have blond hair. However, sensitivity to others' evaluations is encouraged in the distribution of resources due to scarcity and opportunity costs. From this we cannot deduce anything for the values involved in the distribution of traits and talents. It cannot follow, therefore, that luck egalitarians must simply accept current evaluations of traits and distribute those with the highest scores equally. As we will see in Part II, they can develop detailed prescriptions that can guide public policy on genetic engineering, without adopting

that this result is inconsistent with its philosophical commitments. 
implausible assumptions about different traits' value.

\section{Perfectionist Concerns}

A final obstacle that the pursuit of genetic equality poses to luck egalitarianism is that of perfectionist implications. The worry here is not that theorists will strive to create Nietzschean Übermenschen, since their motivation is by definition egalitarian in nature; rather, it is feared that, in practice, genetic equality is doomed to end up resembling Nietzschean perfectionism.

First, it may seem that in order to eliminate genetic inequalities, luck egalitarianism will seek to 'rid the world of undesirables' by endorsing perfectionist judgements on which lives are better lived, and on which people are inherently better than others. In this sense, echoing Elizabeth Anderson's complaint, luck egalitarians' commitment to the fundamental basic equality of all would be shaken ${ }^{13}$. In fact, it may be claimed, not only would states be required to announce who is better, but they would also seek, in the name of justice, to make those who are different just like those better ones. However, as I will show in Part II, luck egalitarianism need not express a commitment to perfectionist judgements about value; in fact, the implications of such judgements in the face of genetic engineering provide a further reason for endorsing a liberal egalitarian theory of justice.

Second, it may be claimed that genetic equality will come to resemble Nietzschean perfectionism because the enhancements it demands are boundless ${ }^{14}$. Let us assume that few people have an IQ of 160; as we raise everyone's IQ to match that level, presumably some persons' IQ will rise further, at least in the longrun, from interacting only with highly intelligent people. Predicting this simple fact will trigger a hunt for perfection. Nevertheless, even if we assume that this is indeed what luck egalitarianism requires, it does not seem obviously true that the consequence of a human species with a high average IQ level is intrinsically bad. Besides, it seems that evolution has been working with the same driving forces, albeit in a slower and natural way ${ }^{15}$. Moreover, there is a morally pertinent difference between seeking to eliminate inequalities caused by brute luck, and seeking to achieve the best that can be achieved at any time. The first motivation can in fact draw certain boundaries to what ought to be pursued, even if time shifts those boundaries, as happens with Darwinian evolution anyway, while the latter is indeed boundless.

Third, it has been claimed that 'use of enhancements may reinforce superficiality, narcissism, selfishness, deceitfulness, laziness, and lack of integrity ${ }^{16}$. However, assuming an anti-perfectionist political morality is adopted, if equality requires certain interventions, we may not plausibly claim that we will sacrifice the requirements of justice because they might have poor consequences for the character of some people. If a potential undesirable effect of technology or medicine on some individuals' character suffices to ban its use altogether, then we ought to ban plastic surgeries and the use of social media as well. Even if a perfectionist line of reasoning is adopted, since such options do not have the same effects on everyone, it seems that certain background psychological and sociological factors should be targeted. For example, the availability of a mobile phone that can take a selfie cannot create narcissism; if we endorse perfectionism and if perfectionist public policy ought to lower such traits, then the pertinent factors have to be addressed. In any case, the argument does not suffice to ban the availability of enhancements.

\section{Part II: Luck Egalitarian Implications}

The criticisms examined display a common fallacy; they assume that, in virtue of luck egalitarians' commitment to the neutralization of the effects of brute luck, they must endorse any neutralization of that luck itself. First, this claim may seem to follow from the view that the neutralization of the effects of luck is defended simply as a second-best solution to the problem that brute luck poses to equality and responsibility. For example, Buchanan, Brock, Daniels, and Wikler argue that certain luck egalitarians have endorsed the 'Resource Compensation Principle' only because it has not been possible to intervene in the natural lottery ${ }^{17}$. Second, it may be argued that even if the primary 
goal is to equalize solely the effects of brute luck, the most effective way of achieving it will implicate genetic interventions ${ }^{18}$. Since we cannot, for example, completely neutralize the inequalities that arise from individuals' different talents, the second-best solution may in fact be to equalize their talents in the first place. Either way, the conclusion reached is that luck egalitarians must advocate genetic equality.

I contend, however, that both claims can only be upheld by focusing on one part of luck egalitarianism, namely, the arbitrariness of brute luck in determining individuals' life chance, and by thereby ignoring the source of the theory's commitments; the principles dictated by Dworkin's ethical individualism. An analysis of these principles within the context of genetic engineering produces policy-guiding prescriptions that identify which interventions are permissible or required from the viewpoint of Dworkinian luck egalitarianism.

\section{Ethical Individualism}

At the heart of Dworkin's theory one finds a set of views on morality, signifying how we ought to treat each other; ethical individualism comprises two principles, which give rise to a commitment to equal concern for all citizens, and to liberal neutrality. First, it is maintained that 'it is objectively and equally important that any human life, once begun, succeed rather than fail $^{19}$. It follows from this principle that political morality must be egalitarian, as states must demonstrate a commitment to providing the structures required for the pursuit of successful lives by all. Second, there is a special responsibility on the part of each agent to ensure that her life be successful. That special responsibility is expressed in the 'right to make the fundamental decisions that define, for her, what a successful life would be', which gives rise to the requirement of political autonom ${ }^{20}$. Therefore, political morality must also be liberal, stressing the significance of the liberty to define and pursue one's conception of the good.

In fact, that significance is a distinctive parameter of successful lives; in order for a life to be successful, it is necessary that the individual living it identify with the conception of the good pursued. Ethical integrity can only be achieved if one 'lives out of the conviction that no other life he might live would be a plainly better response to the parameters of his ethical situation rightly judged, 21 .

We thus arrive to the following considerations, which ought to be taken into account when public policy is designed and evaluated. First, states ought to advance their citizens' well-being, as dictated by the first principle of ethical individualism ${ }^{22}$. Second, a crucial parameter of that well-being is justice, which defines what it means for a state to manifest equal concern for the lives of all; Dworkinian luck egalitarianism dictates that inequalities traceable to brute luck ought to be neutralised. In the absence of justice, citizens face the wrong kinds of challenges, such as satisfying their basic needs. Third, the good life depends further on the extent to which one has achieved ethical integrity, as defined by the special responsibility principle of ethical individualism. What follows from this parameter is a liberal commitment to anti-perfectionism, which automatically places certain constraints on the policies a state may pursue ${ }^{\mathrm{v}}$. For example, a government may not induce or coerce individuals into becoming doctors instead of musicians, on the basis of a belief that the life of a doctor is more successful or worthy than that of an unrecognized musician; if it did, it would violate the requirement of equal concern for individuals' ethical integrity. It seems, thus, that the three considerations produce a liberal egalitarian political morality, with concrete guidelines for the shape of policy-makers' objectives: given that individuals hold different comprehensive doctrines, equal respect for all requires that individuals be free to pursue their conception of the good.

\footnotetext{
'Whether or not Dworkin's theory should be classified as anti-perfectionist is a highly controversial matter. It seems, however, that even if there is a perfectionist element in the philosophical basis of his arguments, he rejects this characterization of his views on public policy.

See Dworkin, R. 'Ronald Dworkin Replies'. In: Burley J (ed) Dworkin and His Critics: With Replies by Dworkin. Blackwell Publishing, 2004:357.
} 


\section{Resolving an Inconsistency}

When this political morality is reviewed in the face of genetic engineering, an inconsistency seems to be exposed: despite endorsing political neutrality, Dworkinian luck egalitarianism requires the state taking a stance on which lives require redress, and therefore an assessment of the value of different consequences of luck; simultaneously, it also requires evaluating the significance of choice.

Luck egalitarianism seems to advocate conclusions that would violate neutrality. For example, if it is public knowledge that scientific skills are valued more than musical talent, and the former can only be enhanced in an individual if the latter is reduced (not a far-fetched scenario given that genetic aptitude in those different areas depends on different sides of the brain), it may be argued that luck egalitarianism requires that the enhancement be performed on at least some disadvantaged members of society. Yet this would be a clear violation of neutrality, as it would involve a public demonstration of the superiority of certain talents and modes of life over others.

One way to avoid this inconsistency is to refrain from giving luck any metaphysical significance in the account of justice; we may say that the unequal effects of brute luck are unjust, without implying that the traits it produces are objectively bad. Clearly, there would be no interpersonal disadvantage ${ }^{\mathrm{vi}}$ from 'low' intelligence in a society where that level would be the norm.

What follows from this view is that, when genetic circumstances have neutral value and cannot be evaluated, justice only concerns the inequalities that arise from brute luck. For example, if being from a certain race causes disadvantages to that person, then the rationale implicitly adopted by the critiques of luck egalitarianism examined in Part I would view luck egalitarianism as prescribing the elimination of disadvantaged races. Viewing a multifaceted

\footnotetext{
${ }^{\text {vi }}$ The interpersonal conception of disadvantage should not be confused with the counterfactual conception, according to which one's position is to be compared with one's position if things had worked out differently; in this case, that would be a society with a different average level of intelligence.
}

theory in this light is clearly implausible, as in situations of discrimination luck egalitarianism requires the alleviation of structural injustices, a requirement that springs from its commitment to equal concern for all.

Similarly, we may place constraints on the interventions that ought to be pursued when genetic traits are considered valuable by only some people, given their religious, moral, and aesthetic views. The implications of luck egalitarianism for this kind of genetic engineering are clear once we draw on the parameter of ethical integrity and the corresponding principle of special responsibility. It follows that a state would never impose or actively encourage interventions that express controversial comprehensive doctrines. For example, Dworkin could not, consistently with his commitments, advocate enhancements that appeal to particular, controversial views on beauty or desirable characteristics. The fear that luck egalitarianism would 'give way to a biotechnologically preserved tyranny of the normality', by requiring that women have 'blonde hair, blue eyes, small waist, big chest, and a tall figure' is therefore misplaced ${ }^{23}$. Similarly, to return to an example I previously touched upon, suppose the skills of civil engineers are valued more than those of musicians, irrespective of their contribution to society ${ }^{\text {vii }}$. Let us suppose further that certain individuals are socially disadvantaged because they possess the latter and not the former skills. If scientific skills can only be enhanced at the cost of musical skills, our commitment to ethical individualism would restrain the state from actively pursuing this form of genetic engineering ${ }^{24}$.

Now, even though we have established that such interventions could never be required by luck egalitarian commitments, a separate question concerns whether they should be allowed. Non-ideal considerations, such as the level of existing inequalities in the resources people hold, the cost, and the price of interventions, are pertinent on this matter. We may reach, however, certain provisional

\footnotetext{
vii It is assumed that there is no collective need for civil engineers.
} 
conclusions in the context of ideal theory, although these may be outweighed by realistic considerations.

If the question concerns competent adults making such decisions for themselves, there is a pro tanto reason in favour of permitting these interventions, in virtue of the special responsibility principle. In the context of ideal theory, two objections may be raised to this claim. First, it might be argued that since the state ought to be concerned with individuals' well-being, as has been established, it should protect individuals from performing irrevocable actions, especially when they carry an element of risk for harm. Nevertheless, we generally accept and should keep accepting that 'people can voluntarily consent to sterilizations, sex change operations, abortions, and plastic surgery ${ }^{25}$. Second, there is a worry that comprehensive doctrines do not reflect one's genuine commitments, as they adapt to match the dominant value that is preferred in society. However, if such preferences were to revoke individuals' decision-making powers, most of our decisions and transactions would be deemed problematic. Indeed, our preferences also adapt to the values our parents or friends may have, and change according to our experiences. That, however, is not sufficient to demand constraints on self-sovereignty; luck is all-pervading in our lives, yet we ought to be able to bear responsibility for our choices. That responsibility, reflected in the second principle of ethical individualism, establishes a pro tanto reason for allowing individuals to pursue their conception of the good even by means of genetic engineering. As I will argue shortly, however, there are limits on this responsibility when the decision to pursue one's life plans directly implicates third parties, such as their children.

It is by now clear that the morality at the heart of Dworkin's theory, ethical individualism, produces significant guidelines and conclusions for the debate on genetic engineering. As we have seen, ethical individualism serves to point out which instances of bad luck ought to be altered genetically and which ought to be altered socially; when the evaluation of the effects of brute luck varies radically among different reasonable conceptions of the good, Dworkinian luck egalitarianism refrains from endorsing genetic interventions. Thus, luck egalitarianism is safeguarded from frequent objections, which misrepresent its claims.

\section{Procreators versus Offspring}

Although ethical individualism produces clear implications for the permissibility of interventions in a one-generation case, in which each person decides for herself, several questions arise when reflecting upon subsequent generations. First, does Dworkinian luck egalitarianism require at least certain interventions, even against the wishes of procreators? Second, to what extent ought the interests of procreators, including the comprehensive doctrines they hold, determine the lives of their offspring? In other words, which genetic interventions on embryos, fetuses, and infants are permissible?

\section{Obligatory Interventions}

The first question poses the issue of obligatory interventions, which parents would not be permitted to deny on behalf of their offspring. Now, contrarily to objectively valueneutral interventions, which may of course obtain subjective value according to individuals' comprehensive doctrines, there are certain interventions to which luck egalitarianism is indeed whole-heartedly committed. These are cases in which there is overlapping consensus across reasonable people, cultures and times on the claim that they are objectively bad or on the less strong claim that they ought to be eliminated. The significance of this consensus is not based on citizens' actual agreement; it rather derives from the fact that it is necessary in order to express equal concern for the special responsibility of each to lead a successful life. The idea of overlapping consensus rests on the reasons individuals have to accept the imposition of certain policies and their consequences on their lives. The imposition of controversial interventions would insult the political equality of all citizens and inhibit their corresponding autonomy to pursue their conception of the good. Thus, Dworkinian luck egalitarianism only demands interventions whose aims all reasonable 
individuals have reason to endorse, regardless of their comprehensive doctrines ${ }^{\text {viii }}$.

Examples of such cases include premature death and extreme suffering, as happens, for example, to individuals who have ALS or TaySachs. In those instances, all individuals would presumably agree that it is desirable to not suffer from these conditions. The fact that certain procreators may desire to refuse those interventions does not override their urgency, which springs from the fact that they are either prerequisites for any reasonable life plan, or they would strongly benefit all reasonable life plans. Indeed, in order to discharge the special responsibility that one bears for her life, it is necessary to possess certain minimum physical and mental capabilities. As parents may not keep their children's nutrition to unacceptable levels, in the age of genetic engineering they may not inflict harm on them. It should be clear that these interventions are not limited to treatments; just as it is important that certain threats to all life plans be eliminated, it is also significant that enhancements that advance most life plans be endorsed. For example, an enhanced immune or memory system and life extension would presumably also meet the consensus criterion.

One way in which we might render the argument action-guiding is by appealing to the idea of hypothetical consent; interventions are required if we have good reason to assume that an unconscious person would consent to them. We may follow John Harris' suggestion that we should imagine an unconscious person in the ER, 'whose condition can be reversed or removed, 26 . If in this scenario we could charge the doctors for being negligent, we have good reason to assume that the intervention is morally required $^{27}$. For example, permanent paralysis would clearly pass the test, while a rhinoplasty would not. Similarly, if doctors could, with no extra risk, increase the patient's life expectancy beyond average, we would not imagine the patient complaining that she would like to have her shorter life expectancy back.

\footnotetext{
viii Following John Rawls' definition, comprehensiveness refers to 'conceptions of what is of value in life', as well as to 'ideals of personal character' and of relationships. Rawls J. Political Liberalism: Expanded Edition. Columbia University Press, 2005:13.
}

When techniques involving gene selection are necessary, the non-identity problem arises. We may not say that a life with ALS, for example, is worse than non-existence. The above argument cannot, therefore, be formulated in a person-affecting manner; instead, we may say that there are impersonal duties to act in certain ways, with certain motivations, even if the consequences of those actions are not good or bad for specific people ${ }^{28}$.

Now the question arises, if there is overlapping consensus on the fact that the aims of certain interventions are universally desirable, why would certain parents ever deny them to their children? Why does the issue of obligatory interventions arise? One example highlights the necessary means that interventions involve. For example, if blood transfusion is required for a procedure, Jehovah's witnesses will deny it; yet this does not imply that they do not view a prolonged life, or a life with no suffering, as something good and desirable. Similarly, it is not utterly unimaginable that certain individuals would oppose the human desire to 'play God', irrespective of the benefits it may bring. The reasons that certain procreators have to refuse these goods to their offspring do not override the reasons that their offspring would have for complaint. Given that procreators are already free to pursue their conception of the good, giving priority to their desires by curbing their offspring's future autonomy to do the same would clearly violate the requirement of equal concern.

A crucial implication of this suggestion is that liberal respect for bodily integrity 'may have to be qualified'; this is because 'the principle of special responsibility would no longer justify allowing a pregnant woman to refuse tests to discover such a defect in an embryo she carries, and the first principle of ethical humanism - an objective concern that any life be successful would counsel mandatory testing, ${ }^{29}$. It may be objected that by this rationale, luck egalitarianism would also require abortions. However, advocates of abortion can clearly not appeal to the interests of the person that will exist. The disagreement springs from disagreement over when life and personhood begin. Given that these matters are so 
intertwined with one's freedom to pursue their conception of the good the state cannot take an absolute stance on them without violating the requirement of overlapping consensus. If it did, it would force individuals to either act in ways that they would equate to murder or to feel that women are treated as second-class citizens. In any case, the issue of abortion cannot be fully addressed on this occasion, as it presents significant differences to any other form of genetic engineering.

\section{Permissible Interventions}

A separate issue for Dworkinian luck egalitarianism asks which interventions, and under what circumstances, parents may permissibly choose for their offspring. The case for the permissibility of interventions rests on the value of reproductive freedom, which further rests on both principles of ethical individualism. The state ought to express equal concern for the special responsibility each has to lead a successful life, according to their conception of the good; a significant part of that conception is found in one's convictions and desires regarding reproduction and upbringing. Having the freedom to raise one's children according to one's convictions, by exposing them to specific moral, aesthetic, religious and other comprehensive doctrines, is usually viewed as central in leading the life one considers to be a success $^{30}$. It follows that respect for individuals' procreative freedom and rights implies the permissibility of raising one's offspring in accordance with reasonable comprehensive doctrines.

On the other hand, certain limits are placed to procreative freedom in order to protect children's interests and rights. When parental decisions are harmful to their offspring, the state may intervene. For example, parents may not abuse their children, even if they really believe that they would teach them 'valuable' lessons. Similarly, they may not harm their children by reducing their opportunities to 'form, revise, and rationally pursue their own conception of the good life', as the principle of special responsibility requires ${ }^{31}$. For example, most countries rightly have a system of compulsory education, which guarantees that children of all backgrounds will have an adequate range of opportunities once they reach an age in which they can follow their own life plan.

A preliminary conclusion that we can reach by combining these two, frequently opposing, requirements of ethical individualism indicates a pro tanto reason to respect individuals' decisions in reproduction and upbringing, with the exception of cases in which the interests of their offspring are compromised.

Nevertheless, this prima facie permissibility of interventions that do not compromise the opportunities of the child opens up the way to allowing 'designer children', by also choosing, say, its sex. In fact, parents may opt for a Caucasian male, as this choice would expand the child's range of opportunities in our non-ideal world. Thus, further limits must be placed on the area of parental choice.

This problematic claim reveals the necessity for a different account of autonomy. For if one endorses a perfectionist account of autonomy, whereby it is viewed as an end-state that ought to be pursued by any means, then parents will in fact have a moral obligation to their children to expand their opportunities by endowing them with all socially desirable characteristics.

However, the principle of special responsibility seems to require a precondition account of autonomy: on this view, autonomy is an on-going process that 'requires one's choices not to be coerced or manipulated by others ${ }^{32}$. A person's autonomy is violated, in this sense, 'if the genes which constitute her and shape her motivations and abilities are manipulated or chosen on the basis of her parents conception of the good ${ }^{33}$. Importantly, this account of autonomy explains why it seems intuitively wrong to choose a child's characteristics, even though if they do not, brute luck will do so anyway. It makes a relevant difference that if the child regrets its traits it will regret a person's choice, rather than an impersonal fact about nature. It should be emphasized here that this point concerns only interventions which can hinder the pursuit of certain conceptions of the good. Increased intelligence and an enhanced immune system, for example, would not reduce one's autonomy in any way, assuming that 
achieving them would not have opportunity costs in terms of abilities and traits, for such traits are consistent with all reasonable conceptions of the good.

Now it may be argued that if Dworkinian luck egalitarians are committed to this account of autonomy, they cannot allow parents to instill in their offspring specific religious or other comprehensive views. However, without taking a stance on such practices of upbringing, it should be stressed that there is, however, a crucial difference between conventional perfectionist parenting methods and controversial genetic interventions; the former are offset by a compulsory public provision of education, freedom of speech, freedom of the press, etc., whereas the latter are inextricably tied to the individual's personal identity.

Therefore, it has become clear that genetic interventions are impermissible insofar as they harm the offspring, or violate its autonomy, when the precondition account is adopted. I have only provided a plausible and non-exhaustive argument available for the luck egalitarian; there may be other ways to safeguard luck egalitarianism, even if a different conception of autonomy is adopted; to the extent that this is not possible, luck egalitarians have reason to reject the conceptions of autonomy that give rise to the charge examined.

While it is not possible to provide a complete examination of all the interventions that Dworkinian luck egalitarianism would view as permissible, this discussion offers certain preliminary guidelines that could provide the basis for further research.

\section{Hypothetical Insurance}

I suggest that the same conclusions that have been reached by an analysis of the abstract morality at the heart of Dworkin's luck egalitarianism, ethical individualism, can also be reached by examining his hypothetical insurance scheme. In fact, this thought experiment also produces certain rough guidelines for problems faced in non-ideal theory. First, it indicates what ought to happen in cases of partial compliance. For example, should a child whose parents have either ignored the moral and legal requirements regarding interventions, or made a bad genetic choice, bear the consequences of that choice? Second, I will argue that hypothetical insurance produces a plausible rationale for the management of scarce resources.

Dworkin's hypothetical insurance scenario asks us to imagine 'what level of insurance against low income and bad luck' individuals would buy, if they all possessed equal resources, if they had no knowledge on the risk for specific forms of bad luck they faced themselves, and if they only possessed information on the average risk of these forms of bad luck, and on 'the availability, cost, and value of remedies for the consequences of bad luck ${ }^{34}$. Let us assume, as Dworkin does, that these individuals know the comprehensive doctrines that they hold. In order to address the intergenerational problem discussed in the Procreators versus Offspring section, we may further suppose that there are also representatives from those generations, who, unaware of their own particular comprehensive doctrines, aim to ensure their autonomy (the preconditions of which include a fair intergenerational distribution of resources).

The results would presumably match the ones derived above. Individuals would first insure against the most serious instances of bad luck, namely those that would seriously hinder any life plan, such as premature death and intense suffering. Subsequently, they would insure against what will come to be perceived as bad luck given the availability of genetic technologies; since prolonged lives would be desired by all, if they were available individuals would ensure that they get the necessary enhancements. In fact, given that all would select those enhancements, prolonged lives would expectedly become the norm, thereby making insurance against their absence intelligible ${ }^{35}$. As these two choices would rationally be made by the representatives of subsequent generations as well, they would have to be obligatory when children's interests came into question. Similarly, individuals would preserve a space of permissible interventions, constrained by the requirements of subsequent generations' autonomy.

Moreover, the representatives of subsequent generations would presumably insure against certain kinds of their procreators' bad 
option luck. If they know that certain procreators will fail to provide them with the necessary interventions, and that certain procedures will be unsuccessful, they will expectedly insure against both instances of bad luck. Similarly, those in the current generation will generally insure against the outcomes of unsuccessful interventions as well.

Lastly, hypothetical insurance offers guidance on the non-ideal consideration of resource allocation in the face of scarcity. Presumably, individuals presented with the relevant facts, and in the absence of information that would generate bias, would reach certain conclusions on where to allocate what amount of resources. Given budget constraints and costs, they would decide which interventions would be a priority in public policy, and which would only be pursued in the case of a budget surplus. These thought-experiments are not useless in a nonideal context; we may safely suppose, for example, that life-prolongation and immunity to cancer would feature highly in that list. From this we can further infer that as long as these interventions are not available, certain kinds of research should be prioritized. Colin Farrelly claims that non-ideal considerations are fatal for luck egalitarianism, as it fails to 'balance the desire for achieving genetic equality with the desire for achieving other kinds of equality and other values ${ }^{36}$. Yet the hypothetical insurance scheme does just that; individuals' decisions will express considered judgments on the trade-offs their budget allows them to make. Two points that will influence those decisions should be stressed. First, the risks that procedures carry are subject to change as science evolves. Second, interventions may be seen as a cost-effective way of reducing the necessity of other forms of public policy in the long-run; for example, if humans become healthier, with better immune systems, it is likely that less will have to be spent on health care. Therefore, the hypothetical insurance thought-experiment serves a twofold purpose; it confirms that the conclusions reached by an analysis of a Dworkinian political morality are sound, and it safeguards luck egalitarianism from the objection that it makes unrealistic demands in our non-ideal world.

\section{Conclusion}

It has thus been argued that luck egalitarianism can, not only survive the prospect of genetic engineering, but also provide us with valuable guidance on how to respond to new genetic technologies. By analyzing the criticisms of luck egalitarianism in the face of genetic interventions, I have exposed the basic underlying argument; these criticisms rely on the claim that luck egalitarian commitments produce a philosophical adherence to genetic equality. On these grounds, luck egalitarianism is discredited, for genetic equality is thought to reduce luck egalitarianism into libertarianism, and to give rise to homogeneity and perfectionist concerns.

We have seen, however, that luck egalitarianism does not necessarily advocate genetic equality. By focusing on the political morality at the heart of one plausible variant of luck egalitarianism, I have developed an account of its philosophical commitments in the era of genetic engineering. More specifically, Dworkin's concept of ethical individualism serves to identify the interventions that justice requires, while preserving the value of political autonomy. It seems likely that different luck egalitarian theories that give rise to nonperfectionist public policy prescriptions will yield similar conclusions. What the critics have revealed is the necessity of safeguarding luck egalitarianism from the adoption of controversial judgments on the good, which would expose the theory to morally reprehensible interventions.

Certainly, the prescriptions developed are of a pro tanto nature; in order to fully endorse their conclusions, we ought to explore a variety of non-ideal considerations, including the risk and cost of interventions. Moreover, once these concerns are addressed, new issues will arise, such as the permissibility of the provision of obligatory interventions to those who can pay, when these cannot be offered to all. It seems that Dworkinian luck egalitarianism, along with the philosophical tools it offers us, will be in a position to offer plausible answers. 


\section{Acknowledgements}

I am grateful to Tom Parr, Laura Valentini, Matthew Clayton, and David Ventura for their thoughtful comments and support.

\section{References}

1. Huxley A. Brave new world. Harper \& Brothers Publishers, 1932.

2. Gallagher J. 'Designer Babies Debate Should Start, Scientists Say. The BBC, 19 January 2015. http://www.bbc.com/news/health-30742774. Accessed on 01/03/2015.

3. Buchanan A, Brock D, Daniels N, Wikler D. From Chance to Choice: Genetics and Justice. Cambridge University Press, 2000:67.

4. Wolff J. Economic Justice. In: LaFollette H (ed) The Oxford Handbook of Practical Ethics. Oxford University Press, 2003:456.

5. Burley, J. Morality and the New Genetics. In: Burley J (ed) Dworkin and His Critics: With Replies by Dworkin. Blackwell Publishing, 2004:187.

6. Farrelly, C. Genes and Equality. Journal of Medical Ethics 2004a, 30:587-592.

7. Dworkin, R. Ronald Dworkin Replies. In: Burley J (ed) Dworkin and His Critics: With Replies by Dworkin. Blackwell Publishing, 2004:363.

8. Ibid, p. 363.

9. Buchanan A, Brock D, Daniels N, Wikler D. From Chance to Choice: Genetics and Justice. Cambridge University Press, 2000:84.

10.Dworkin, R. Sovereign Virtue: The Theory and Practice of Equality. Harvard University Press, 2000:439.

11.Farrelly, C. Genes and Equality. Journal of Medical Ethics 2004a, 30:587-592.

12.Dworkin, R. Sovereign Virtue: The Theory and Practice of Equality. Harvard University Press, 2000:441.

13. Anderson 1999, 303 Anderson, E. What Is the Point of Equality?. Ethics 1999, 109:287-337.

14.Temkin, L. What's Wrong With Enhancements. Journal of Medical Ethics 2013, 39:729-731.

15.Harris, J. Enhancing Evolution: The Ethical Case for Making Better People. Princeton University Press, 2007: 4.
16.Temkin, L. What's Wrong With Enhancements. Journal of Medical Ethics 2013, 39:729-731.

17. Buchanan A, Brock D, Daniels N, Wikler D. From Chance to Choice: Genetics and Justice. Cambridge University Press, 2000:84.

18.Hunter, D. Are New Genetic Technologies Unlucky for Luck Egalitarianism? Ethical Perspectives 2012, 19:33-54.

19.Dworkin, R. Sovereign Virtue: The Theory and Practice of Equality. Harvard University Press, 2000:448.

20.Ibid, p. 449.

21.Ibid, p. 270.

22.Clayton, M. A Puzzle About Ethics, Justice, and the Sacred. In: Burley J (ed), Dworkin and His Critics: With Replies by Dworkin. Blackwell Publishing, 2004:100.

23.Fox, D. Luck, Genes, and Equality. Journal of Law, Medicine and Ethics 2007, 35:712-726.

24.Clayton, M. Individual Autonomy and Genetic Choice. In: Burley J, Harris J (eds), A Companion to Genethics. Blackwell Publishing, 2002:197.

25.Wertheimer, A. Two Questions About Surrogacy and Exploitation. Philosophy \& Public Affairs 1992, 21:228.

26.Harris J. Enhancing Evolution: The Ethical Case for Making Better People. Princeton University Press. 2007: 92.

27.Ibid, p. 93.

28. For a detailed analysis of the non-identity problem see Parfit D. Reasons and Persons. Oxford University Press. 1987: chapter 16.

29.Dworkin, R. Sovereign Virtue: The Theory and Practice of Equality. Harvard University Press, 2000:450.

30.Brighouse H, Swift, A. Parents' Rights and the Value of the Family. Ethics 2006, 117:80-108.

31.Quong, J. Liberalism Without Perfection. Oxford University Press, 2010:9.

32. Clayton, M. Individual Autonomy and Genetic Choice. In: Burley J, Harris J (eds), A Companion to Genethics. Blackwell Publishing, 2002:201.

33.Ibid, p. 202. 
34.Dworkin R. Justice for Hedgehogs. Belknap Press of Harvard University Press. 2011: 360.

35.Dworkin R. Ronald Dworkin Replies. In: Burley J (ed) Dworkin and His Critics: With Replies by Dworkin. Blackwell Publishing, 2004:364.

36.Farrelly C. The Genetic Difference Principle. The American Journal of Bioethics 2004b, 4:21-28. 